\title{
ELECTIONS IN NIGERIA \\ IS THE THIRD TIME A CHARM?
}

\author{
By \\ A Carl LeVan, Titi Pitso, Bodunrin Adebo
}

A Carl LeVan is a PhD candidate in the Department of Political Science at the University of California, San Diego, 9500 Gilman Drive La Jolla, California 92093-0521 USA; Tel: + (1) 619-865-4255; Fax: + (1) 858-534-7130; e-mail: clevan@ucsd.edu Titi Pitso is Elections Consultant at the African Centre for the Constructive Resolution of Disputes, Private Bag X018 Umhlanga Rocks 4320 South Africa; Tel: +27 31502 3908; Fax: +27 31502 4160; e-mail: jpitso@hotmail.com

Bodunrin Adebo is Program Officer of the National Democratic Institute, Plot 364 Off Aminu Kano Crescent Wuse 2, Abuja Nigeria

Tel: +(234) 9-523-3341; Fax: +(234) 9-523-3467;

e-mail: joeadebo@aol.com

\section{INTRODUCTION}

The April 2003 elections in Nigeria, the first civilian administered elections to take place in two decades, were hailed as the largest in African history and are surely a major milestone for both the country and the continent. Although they were marred by serious irregularities they were historic - instead of a military coup, a civilian government was to be succeeded by another civilian government.

President Olusegun Obasanjo won with 62 per cent of the vote, and his party scored huge victories in the National Assembly and the State Assembly elections. In the face of predictions of violence, Nigerians defied the odds and went to the polls peacefully in most parts of the country. Turnout was high, and there also appeared to be a respectable geographic spread of the winning party's base of support. But these encouraging facts and other optimistic assessments of the elections offer only superficial portraits of an outcome that remains far more uncertain.

Prior to the elections problems arose with the electoral framework and undermined confidence in the process. Other serious concerns were the high incidence of violence in the pre-election period, especially during the party primaries, and shortcomings in the voter registration and voter education process. These problems helped create an unstable climate for the elections.

The electoral commission addressed many of the inefficiencies that arose during the National Assembly elections, but serious irregularities in the presidential and gubernatorial elections the following week brought the results in some areas 
into question. The main opposition party has yet to accept the results. Because of these problems it is difficult to say whether Nigeria is measuring up to the standards of democratic consolidation commonly used by political scientists.

However, on several grounds the elections may be viewed as a positive step towards democratic consolidation. One view is that elections, in and of themselves, constitute an important step forward. Huntington (1991) advances the notion of a 'two-turnover test' whereby democracy is consolidated 'if the group that takes power in the initial election at the time of transition loses a subsequent election and turns over power to those election winners' who, in turn, do the same in another election. Karl and others warn against such an 'electoral fallacy', whereby elections are legitimation rituals but may say little about civil and political rights and other liberal dimensions of democracy (Diamond 1996, pp 20-37; Karl 1990, pp 1-21). Bratton (1999) stakes out a middle ground in the debate, saying 'elections and democracy are not synonymous'. 'Elections remain fundamental, not only for installing democratic governments but as a necessary requisite for broader democratic consolidation.'

By all measures Nigeria has yet to pass Huntington's two-turnover test. In 1964 the Northern People's Congress (NPC) managed to defeat the incumbent parliamentary coalition, but the so-called First Republic soon degenerated into violence and a military coup. In 1983 Shagari's National Party of Nigeria (NPN) narrowly won re-election in a contest among six presidential candidates, meaning no turnover occurred. This government was also terminated by a military coup. In Nigeria's present and third attempt at democracy, nationwide polls indicate strong support for democracy over military government and security forces appear to have played a largely positive role in the 2003 elections. In addition, those who lost and who might be tempted to organise against democracy seem to have little support from the military, which continually states its public commitment to democracy. In order to avoid the fate of the First and Second Republics it is necessary to have an apolitical military, but the cost has been high as Obasanjo has been unable to hold anyone accountable for serious human rights violations that took place under his administration.

A broader benchmark for measuring democratic consolidation is simply the alternation of power, without specifying two turnovers or two elections. Alternation of power is only possible where vigorous political competition exists. Dahl (1971) famously listed 'public contestation' along with participation as a key ingredient of 'polyarchy', his ideal type of democracy. Rustow (1970, pp 337-63) referred to democracy as 'a system of rule by temporary majorities'. And Mainwaring (1992) identifies a procedural requisite of democracy as the 'opportunity to get rid of rulers who lose their popular support'. In Nigeria the presidency did not change hands, but there was significant turnover at other levels of government and this could be taken as an encouraging sign. For example, eight of the 36 incumbent governors lost in 2003 and, as discussed below, the turnover among the National Assembly rank and file as well as the leadership was substantial. Yet much of the change 
occurred within parties rather than between them - high turnover should not be equated with alternation of power. Moreover the ruling People's Democratic Party (PDP) was unwilling to risk losses in some states at any cost, while many opposition parties have been unwilling to concede losses.

Finally, and most significantly, the national scope of the PDP support could be interpreted as a positive step towards consolidation. The democratisation literature has emphasised the importance of cross-regional and multiethnic support in a plural society (Lijphart 1977; Lijphart 2002, pp 37-54; Mainwaring 1992). Linz and Stepan (1996), for example, write the more the population of the territory of the state is composed of pluri-national, lingual, religious, or cultural societies, the more complex politics becomes because an agreement on the fundamentals of democracy will be more difficult'. In Nigeria the political geography consists of six 'zones', each one roughly with its own common economic, agro-climatic and ethnic qualities. The PDP secured more than a quarter of the vote in 32 of the 36 states in the presidential election, making surprising inroads into the Yoruba South West zone, securing a solid base in the South East among the Igbos, and garnering the support of many minorities in the South South. Results in the National Assembly and State House elections reflect these patterns as well. Only in the North West, where Mohammadu Buhari and his All Nigeria People's Party (ANPP) leaned towards conservative Muslim society, did the PDP falter. Obasanjo and the PDP may have overcome ethno-regionalism but inter-party competition has never been weaker in Nigeria's three democratic regimes. This raises the question of whether inter-party contestation is being replaced by the emergence of one 'super party' and intraparty competition.

\section{The Pre-Election Environment}

The period leading up to the elections showed some promise in terms of voter participation and the role of the courts. Although the registration process was flawed, 61 million voters registered and the electoral commission implemented technology to reduce duplicate registration. When various disputes arose concerning voter and party registration and electoral law Nigerians utilised the courts as an independent third party with the credibility to resolve contentious issues, and judicial decisions over electoral law were largely accepted as binding.

Other aspects of the pre-election environment were less encouraging. Many party primaries were chaotic and, when they occurred at all, they were nontransparent processes whose results were often hotly disputed. Serious incidents of political violence against candidates and party officials were common, but investigations rarely led to prosecution, contributing to a climate of mutual mistrust and impunity. Finally, when local government elections did not take place as scheduled, governors imposed 'caretaker' governments at the local government (LGA) level. The presence of these un-elected officials gave incumbent parties a distinct organisational advantage at the state level and undermined confidence in 
the overall process. In sum, the relative success of the registration process and the frequent use of the judiciary as neutral arbiter must be weighed against a combination of an extraordinarily weak primary process, impunity for political violence, and the weakening of democracy at the local level by the appointment of un-elected local governments.

\section{The registration process}

Voter registration suffered from several setbacks that affected overall enfranchisement and therefore confidence in the electoral process. ${ }^{1}$ Problems included logistical delays, insufficient staff training, lack of security at registration centres, poor voter education campaigns and other flaws. After various delays the ambitious new computerised registration process was implemented in September 2002. The process required registration staff to fill in complex computer readable forms but inadequate staff training resulted in further delays and confusion. Additional confusion stemmed from unclear lines of responsibility for voter education. The Independent National Electoral Commission (INEC) claimed that educating voters was not part of its constitutional mandate so it made few efforts to do so. Government support for voter education was relegated to the National Orientation Agency (NOA), a state propaganda agency which carried out some limited voter awareness campaigns. Several reports by election observers noted that political parties did not conduct voter education properly, leaving the task instead to non-governmental organisations. The resources of many domestic NGOs were already stretched because of their involvement in monitoring registration and training staff for election monitoring; both of these tasks were unnecessarily complicated by the INEC's initial reluctance to accredit many domestic observers. The result of this confusion over responsibility for voter education was low registration at many registration centres, particularly in the first round of the process.

The most serious problems probably involved the actual distribution of registration materials. The initial registration period only lasted for ten days, giving registration centres little time to compensate for shortages of materials. In many parts of the country shortages appeared to be calculated and there were many credible reports of party officials hoarding forms or distributing them to loyalists. INEC attempted to address these problems by extending the registration period for two days and improving its cooperation with domestic monitoring organisations. Although the short registration period was apparently intended to reduce opportunities for fraud, the reverse appears to have been the case as the scarcity of materials helped drive corruption and generate voter cynicism. Since materials were only available for a short time they, in effect, became much more valuable, and whatever well-meaning officials there were had little time to redirect materials

1 Some of this information can be found in two reports on the 2003 Nigerian Electoral Process issued jointly by the National Democratic Institute and the Carter Center in November 2002 and March 2003. 
to areas where they were needed or to investigate irregularities. In response to these problems INEC re-opened the registration process briefly in January 2003.

After registration INEC failed to publish the voter lists in virtually every area, as required by s 10(1) of the Electoral Act of 2003. This meant that many voters did not know their registration status until election day. According to observers, the failure by INEC to display the voter list in many areas made it difficult to ascertain the authenticity of the register or allow voters to query their registration status. Reports by domestic observers suggest that the figure for voters not included in the register may have been as high as ten per cent. In the end, 61 million voters registered and approximately seven million were eliminated because of duplication or invalid thumbprints detected by the computer scanning system.

\section{Party primaries}

Political party primaries were marred by delays, weak internal democratic processes and, in several cases, by violence. For example, the Edo State chair of the ANPP was kidnapped in January in connection with a dispute over the party's gubernatorial primaries (Amaize 2003). As in 1999, the primaries were basically closed affairs. In that year the All People's Party (later renamed the ANPP) picked Chief Olu Falae as its presidential candidate during a secretive meeting in Ibadan. This time around the ANPP picked its candidates amidst accusations of fraud from five other contenders - all southerners - who withdrew in protest (UNIRIN 14 January 2003; Vanguard 2003). The Kano State PDP primary was postponed for months because of internal disputes. The primaries in Anambra State were allegedly rigged and pre-determined, with sheets listing the names of candidates being certified even before voting took place (Onyekamuo 2003). The All Progress Grand Alliance (AGPA) only succeeded in nominating its candidate after the abrupt expulsion of three national executive officers (Aziken 2003). The Transition Monitoring Group (TMG), a coalition of 170 civil society organisations, condemned the primaries of both the ANPP and the PDP, alleging widespread bribery. According to one report, 'Undue pressure, including subtle threats and intimidation, were employed by agents of the government to compel delegates to vote in favour of the preferred aspirants (UNIRIN 21 January 2003).'

The most contentious primary clearly involved Alex Ekwueme, who challenged Obasanjo for the PDP presidential nomination. Ekwueme, the former vice-president in the Second Republic, was defeated in the primaries, receiving only 17 per cent of the vote of the party's 3000 delegates. Ekwueme took his grievances to the courts, where his case stumbled. But the PDP was deprived of the compelling image of legitimacy that its 1999 primaries had enjoyed when, after losing, Ekwueme raised Obasanjo's arm in a show of solidarity. This time, after losing the 2003 primaries, Ekwueme withdrew and other influential PDP officials joined other parties (Ughegbe 2003; Ojeifo 2003). Perhaps the most dramatic evidence of disillusionment within the PDP was the unusual, if not bizarre, defection 
from the party in December and January of ten senators and representatives, within a one-month period and with the presidential election not far off. The former Deputy Senate President, Haruna Abubakar, led 65 gubernatorial primary candidates in rebellion against the PDP leadership. When the protest failed, he and many others went to court and then opened discussions with the ANPP (This Day January 2003).

\section{The courts}

The use of courts in new democracies is generally seen as a positive step towards democratic consolidation (Linz and Stepan 1996; Schedler, Diamond et al 1999). But parties also file claims for delay, obstruction or other reasons and this can contribute to an environment of permanent uncertainty about the results. In addition, whether the judiciary plays a positive role largely depends on whether the courts are seen as independent and fair, otherwise their decisions may not be accepted. Historically this has been an issue in Nigeria, most notably in the Second Republic, where neither candidate satisfied the two constitutional requirements for election: a plurality of votes nationwide and 25 per cent of the vote in twothirds of the states. As a result of the impasse, several parties unsuccessfully pushed for a run-off. The Federal Electoral Commission declared Shehu Shagari of the National Party of Nigeria (NPN) the winner, based on an interpretation of electoral law that declared two-thirds of 19 states to be 12 rather than 13. The electoral tribunal, and eventually the Supreme Court, upheld the Federal Election Commission's decision (Falola and Ihonvbere 1985; Oyediran 1981). General Olusegun Obasanjo (then the military dictator) accepted the Supreme Court's conclusion but his Yoruba kinsman allegedly resented his decision to hand over power to the northern-based NPN. The 1983 elections were marred by violence and the Yoruba states voted overwhelmingly against Obasanjo when he ran for President in 1999.

In the period leading up to the 2003 elections the courts addressed three types of conflict: internal party disputes, executive-legislative disagreement, and challenges to INEC's decisions. Ekwueme's legal intrigues fall into the first category. Another example of this is Jigawa State, where a former Cabinet minister successfully challenged in court the governor's choice for the ANPP gubernatorial ticket (Kalu April 2003). In the second category, the courts in 2002 struck down changes in s 15 of the 2002 Electoral Act that required all elections to take place on the same day. Shortly before the election the Office of the President filed a separate case challenging the validity of the National Assembly's veto override of the electoral Bill, claiming that the Constitution required two-thirds of all members (rather than only of those present) to vote in favour of the override. Had the President's lawyers succeeded, the provisions of the Electoral Act of 2001 would have been upheld, calling for presidential elections before legislative elections. INEC also went to court to void the Electoral Act of 2002 when it required all polls 
to take place in one day. Officials claimed that would be logistically difficult. INEC also argued that under the Constitution only it is empowered to fix the dates of the elections, and therefore a simple legislative motion cannot change the electoral Bill (Fadeyi and Soniyi 2002). ${ }^{2}$ These cases also unfolded in a context where INEC had been complaining about lack of funds and the Executive had successfully convinced the public that the National Assembly was to blame. This is only partly accurate, as in 2001 it was the Federal Government that delayed the release of funds to INEC, thereby slowing down the registration process (Transition Monitoring Group 2003).

Challenges to INEC, the third type of case, involved agitation by the smaller parties. These cases were all the more problematic given that the incumbent president had earlier dismissed all the members of INEC and unilaterally replaced them. When INEC failed to display voters' lists at least 60 days before the elections, as required by law, the National Democratic Party (NDP) took INEC to court. The courts, concerned about the dangers of forcing a postponement of the elections, rejected the challenge by the NDP.

Another problem was that at first only a handful of parties was recognised by INEC. Smaller parties also complained about exorbitant registration fees, which they claimed were designed to keep them out of the political process. When the parties won in court, INEC immediately showed its reluctance to implement the decision and the federal Attorney General sided with it, stating that the fact that a party meets the qualifications for registration does not mean registration is 'automatic'. Meetings between the executive branch and the court resulted in the court claiming to have made a 'clerical error' in the decision that had ruled in the new parties' favour (Ughegbe and Akoni 2002; Anaba. 2002). Eventually the Commission was forced to recognise a total of thirty parties, although only 22 fielded presidential candidates.

The mere fact that Nigerians resorted to the courts showed that they had confidence in their legal system and, as discussed above, there was enough fairness in the proceedings and ruling of the courts for one safely to say that they were seen as credible by most Nigerians.

\section{Political violence}

Just prior to the elections candidates jockeying for party support partly fuelled tensions, which, in numerous cases, assumed violent proportions. Most intra-party violence occurred at the state level and related to party primaries - the ruling party had more intra-party violence than other parties.

On 19 March 2003 President Obasanjo convened a Peace Summit of all the political parties with the aim of encouraging all parties to work for peaceful elections.

2 The relevant sections of the Federal Constitution in INEC's complaint are ss 78, 118, and 58(5). It should be noted that Shugart and Carey (1992) have demonstrated that when presidential elections are held before legislative elections there tends to be a 'contamination effect' on the outcome. 
Though the Summit was well attended party leaders failed to utilise the opportunity afforded to commit themselves and their parties to peace-building mechanisms.

In the period between mid-2002 and the elections hundreds of political figures, including prominent opposition politicians, were killed. Just prior to the elections Human Rights Watch issued a report documenting dozens of such cases and stating, 'political violence poses a serious threat to the legitimacy of the state and federal elections (Human Rights Watch April 2003)'. For example, in September 2002 Barnabas Igwe, a prominent reformer with the Nigerian Bar Association, was killed in Anambra State after calling for the governor's resignation for failing to pay civil servants. That same month Isyaku Mohammed, the deputy chair of the new opposition party, the United Nigeria People's Party (UNPP), was killed in Kano, a key battleground state in the elections (Human Rights Watch April 2003). In March 2003 Marshall Harry, the vice-chair of the ANPP in the South South (one of Nigeria's six geographical 'zones') was killed in his Abuja home. Critical of the PDP government in his home state of Rivers, he had decamped to the ANPP. The most prominent murder was probably that of Federal Justice Minister Bola Ige, who was killed in December 2001, shortly after violence in the Osun State Assembly that left one representative dead. Human Rights Watch noted that such violence generally occurred in a climate of impunity and with little reaction from the international community.

Other violence was clearly inter-party. One PDP / ANPP dispute, utilising hired 'mercenaries', in Benue State, left seven people dead. Another incident, in Gombe State, involved an attack by ANPP supporters on the PDP gubernatorial candidate and the Minister of State for Mines and Power, who were travelling in a convoy (Ior February 2003; Ibrahim February 2003).

And just days after he lost the race in Kwara State, the ANPP candidate for a House seat was hacked to death with a machete (Ilorin April 2003, p 5). In the two weeks leading up to the elections alone, the Institute for Democracy in Southern Africa (IDASA), in its weekly report, titled 'IDASA Weekly Updates on Election Related Violence and Conflict' reported the following incidents of political violence:

- In the Niger State Progressive Redemption Party (PRP) supporters attempted an attack on the governor's convoy.

- Mohammadu Buhari, the ANPP presidential candidate, was attacked in Adamawa State, which is a PDP stronghold.

- In Ondo State the campaign convoy of Chief Gani Fawehinmi, presidential candidate for the National Conscience Party (NCP), was attacked.

- Seven people were injured in a gunshot and machete attack on the Oyo State governor, Alhaji Lam Adesina.

- In Abuja six gunmen raided the house of the spokesperson for the PDP Presidential campaign, Osuntokun, but he was not at home.

- In Plateau State suspected raiders from Chad, motivated by ongoing ethnic tensions between the Fulani and the Tarok, attacked the indigenes of Dwei 
village between Langtang and Wase local government councils. Violence and intimidation between the ANPP and PDP gubernatorial candidates became so serious that President Obasanjo considered withdrawing the security officials attached to both candidates and threatened other punitive action.

- In Zamfara police warned religious leaders to steer clear of politics in their sermons. In an effort to avert violence, political parties, after an interparty consultative forum, decided to suspend political rallies throughout the state.

The geographical distribution of and widely shared blame for this violence suggest it was indeed a widespread problem, and the government's stern approach failed to ease tensions. After the ANPP and other parties announced that, instead of a boycott they would organise a 'mass action' at the presidential polls, the Chief of Defence Staff said the military 'cannot sit down and see the loss of lives and property. It will not be allowed. Even the Constitution says members of the Armed Forces can render assistance to civil authority when the need arises (Omonobi, Yacoob and Ajayi 2003, p 1).' Equally alarming were comments by the Inspector-General of Police, who, in promising to maintain order during the presidential elections, advised his officers, 'Be prepared to maim or cripple any person, no matter how highly placed, who attempts to disrupt the forthcoming polls. You don't need any directive from me to do this (The Post Express April 2003).' The permissive climate fostered by such statements continues. If it remains unchanged it will likely undermine both the perception of law enforcement agencies and the likelihood of peaceful political competition leading up to the next election. Moreover, most cases of election-related violence remain unsolved, offering little fear of sanction among those who might be tempted to repeat such tactics in the future.

\section{The 2003 ELECTIONS}

\section{The electoral framework}

The national elections took place in three stages. Elections for the National Assembly were held on 12 April and gubernatorial and presidential elections the following weekend, on 19 April. Finally, State Assembly elections took place on 3 May. Although there were 30 parties on each ballot three major parties contested the elections. First was President Obasanjo's PDP, which held a majority of seats in both the House of Representatives and the Senate. Second was the ANPP, headed by Muhammad Buhari. The party had a strong base in the country's Hausa-Fulani North West region, where conservative Muslims in twelve states challenged the federal government by adopting a criminal justice system based on Islamic law. The contest between the ANPP and the PDP was unusual in that both major candidates were former military dictators: Obasanjo (from 1976 to 1979) and Buhari 
(from 1983 to 1985). The third major party in the elections was the Alliance for Democracy (AD), a party with historical roots in Obafemi Awolowo's Unity Party of Nigeria (UPN) and its predecessor, the Action Group, with strong roots in the Yoruba South West. Aside from these three major parties the party system was highly fragmented. Many of the remaining 27 opposition parties attempted to form a united front, the Conference of Nigerian Political Parties, but failed to agree on a consensus candidate.

\section{Notable election outcomes}

In the context of Nigerian politics there are at least four notable outcomes of the elections. One factor that garnered a great deal of international attention was the irregularities that brought the results into question. There is evidence based on independent observation by domestic and international monitors to suggest that the fraud and intimidation were widespread and serious (FOMWAN \& MULAC; Transition Monitoring Group; International Republican Institute April 2003; National Democratic Institute April 2003). ${ }^{3}$

One report by Muslim civil society organisations, based on 1100 observations, claimed that at 76 per cent of the polling units the number of votes received by parties did not equal the number of ballots cast.

Observation groups also reported that voters with proper accreditation were refused the right to vote and there were serious violations of secrecy, although some of these seem to have been the result of misunderstanding of procedures.

Under-age voting was a problem in many rural areas such as Kogi, Adamawa, and parts of Kaduna. The stuffing of ballot boxes was observed in several states. Election day violence was serious in states such as Edo, Delta, Bayelsa, Cross River, and Anambra. In some cases it was so serious that elections in those states were postponed or rescheduled.

The National Democratic Institute's delegation concluded: 'The cumulative effect of these problems seriously compromised the integrity of the elections where they occurred and will most likely erode public confidence in the electoral process.' This sort of strong wording from civil society leads Bratton to suggest that second elections in Africa carry contradictory messages about the consolidation of democracy: when civil society mobilises to prevent election fraud it simultaneously undermines the consensus necessary for constituting the new government (Bratton 1999). This tension between civil society and the government remains and could provide an outlet for new sources of opposition focused on questioning the government's legitimacy.

Press release by Federation of Muslim Women's Associations in Nigeria (FOMWAN) and the Muslim League for Accountability (MULAC); 'Preliminary Report on the National Assembly Elections', issued by the Transition Monitoring Group; 'Election Observation Mission Preliminary Statement', issued by the International Republican Institute, 21 April 2003; 'Preliminary Statement on the International Election Observer Delegation', issued by the National Democratic Institute, 21 April 2003. 
Another outcome is the extraordinary defeat the Alliance for Democracy (AD) suffered in the legislative and gubernatorial elections. In the National Assembly elections the AD lost 11 of its 16 Senate seats and 38 of its 60 House seats. It suffered losses even in states where it was previously strong: in 1999 it had held all 12 Senate seats in Ogun, Ondo, Osun and Oyo, but after the 2003 elections it held only two of these seats. In the intervening period, preceding the presidential and gubernatorial elections, the disappointing performance of the $\mathrm{AD}$ precipitated tense internal debate, with various incumbent governors proposing they abandon the pact with the PDP. Lagos State's popular governor Tinubu and others urged caution. Detecting an opportunity, the ANPP presidential candidate, Muhammadu Buhari, made a last-ditch and ultimately unsuccessful attempt to win votes in the South West two days before the election. In the final tally the losses were even more profound in the gubernatorial elections, where the $\mathrm{AD}$ lost every race but one. The governors of Oyo State and Ondo State, who both campaigned with Tinubu for the re-election of Obasanjo, lost their re-election bids to the PDP (with a significant delay in the reporting of the complete results for Lagos State). In Ogun State the PDP defeated the $\mathrm{AD}$ by 64 to 33 per cent and the governor-elect commented that by not running a presidential candidate the $\mathrm{AD}$ was left without any leverage or political capital to negotiate with (Adeniyi April 2003, p 1).

\section{Distribution of Governorships After the 2003 Election By Zone and State*}

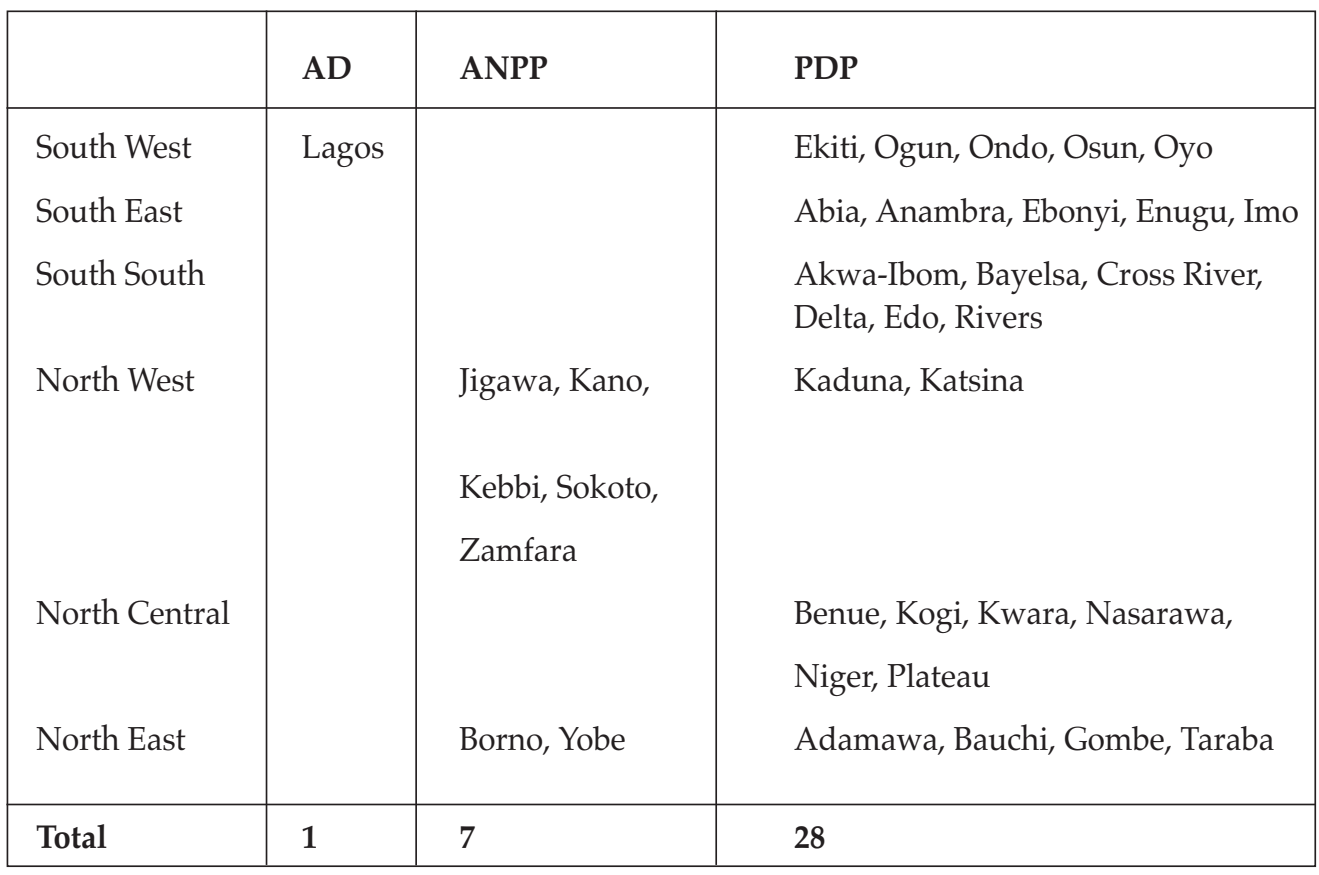

* Abuja, the Federal Capital Territory, does not have a governor 
The poor performance of the AD in the National Assembly and gubernatorial races leaves the South West in the paradoxical position that, despite having a Yoruba president, many ethnic Yorubas may feel under-represented. Chief Abraham Adesanya, leader of the ethno-political organisation Afenifere, first expressed his frustration with the PDP when he and all six of the AD governors met with President Obasanjo after the National Assembly elections.

Adesanya warned against another betrayal of Yorubas (as the 1979 election debacle was perceived). 'What you sow, you reap,' he cautioned. 'If the PDP continues to do what the NPN did in those days and feel that they can get away with it, it is a delusion (Akinola April 2003, pp 14-15).'

There is good evidence that the AD's weak standing is directly related to its decision not to run a presidential candidate. In other words, its Assembly and gubernatorial candidates lacked 'coat-tails'. It was an open secret, widely reported in the press, that the AD had decided early on to throw its weight behind Obasanjo in exchange for Cabinet positions and other benefits later. Some in the PDP questioned the sincerity of the $\mathrm{AD}$, suspecting that it would try to advance Obasanjo as its own candidate, rather than a joint candidate, or accusing the party of endorsing him merely because of his ethnicity. 'Why can't they just present a front by sponsoring an unknown candidate who will garner very few votes?', asked one PDP politician in Kano (Olaniyonu February 2003). Unfortunately for the AD, the decision not to field a candidate before cutting a deal - as they did in 1999 - proved devastating, leaving its House, Senate, and gubernatorial candidates without the benefit of any coat-tails to run on.

The absence of coat-tails was further compounded by electoral coalitions that occasionally undermined the AD or even advanced the ANPP. Describing the situation in Brazil, Samuels (2003) called the phenomenon of party coalitions at the sub-national level undermining the party's objectives at the national level 'incongruent coalitions'. At the eleventh hour, seven parties in Lagos State endorsed the PDP gubernatorial candidate and called for a 'unity government', even though they were fielding presidential candidates of their own (ThisDay April 2003, p B2).

An even more contradictory phenomenon emerged in Kwara State, where the ANPP formed a coalition with two other minor parties in the interests of defeating the PDP candidate, Olusola Saraki; an advertisement listing the names of PDP members gave the impression the PDP had endorsed the ANPP. The PDP, for its part, recruited six parties to endorse its candidate. The contest in that state stemmed from a bitter dispute between Governor Mohammed Lawal of the ANPP and his 'godfather', or patron, Saraki, who left the ANPP for the PDP in 2002. The rivalries led to the murder of the state chairman of the PDP, the bombing of a pro-Saraki newspaper, and an attack on a wedding attended by Saraki supporters, in which two people were killed. Saraki won the contest, and his daughter defeated the incumbent to secure a Senate seat (The Comet April 2003, p 5; Human Rights Watch April 2003; Adebayo April 2003, p 8). ${ }^{4}$ 
A third significant outcome of the elections was the unusually high degree of turnover generally. In the Senate, leaders of each of the three parties have all departed: the PDP leader lost the gubernatorial race in Sokoto; the ANPP leader won the gubernatorial race in Borno State; and the AD Senate leader from Osun State lost his seat to a former deputy governor from the PDP - who, at the time of the election, was in prison on charges relating to the murder of the justice minister (Obi and Adeyemo April 2003, p 1). The Senate President opted not to run for reelection; his deputy was declared defeated; then the results of the race were abruptly reversed (Oderemi April 2003).

Others resigned to run for president. They included Ike Nwachukwu, who ran on the National Democratic Party ticket, and Jim Nwobodo, who carried the banner of the United Nigeria People's Party. In elections for the House, the Speaker was roundly defeated. This defeat was related to his controversial campaigns to impeach the President and, most notably, his suspension from the party only three days before the elections for 'anti-party activities (Akunna April 2003, p 1)'. It was widely believed that the PDP actually used state machinery, even on polling day, to make things difficult for his re-election.

This high turnover should be interpreted with a few notes of caution. There were probably some reformers among those who were defeated, while others were weeded out through closed party primaries rather than open-secret ballot (a means of casting and counting ballots that is intended to guarantee the privacy of the individual voter and the transparency of the collective results). Moreover, the turnover must be interpreted in light of the large number of legislators who either opted to run for other elected offices or who voluntarily stepped down. In other words, it is far from clear whether they were defeated by a vigorous and effective opposition or if they were rotated out by their party's notion of 'power shift' - that it is someone else's turn to eat at government's table.

A final notable outcome is Obasanjo's redemption by the Yoruba electorate in the South West zone. As the presidential candidate for the PDP in1999 he failed to carry even one state in the South West, either because there were two Yoruba candidates in 1999 or because of lingering resentments over the 1979 debacle. After the 1979 election Obafemi Awolowo and the Unity Party of Nigeria were furious with General Obasanjo - then the military head of state - for handing over power to the NPN, which was seen as the successor to the Northern People's Congress, a predominantly Hausa-Fulani party in the First Republic.

It would take nearly 25 years for Yoruba voters to forgive Obasanjo for 'handing over power' to the Hausa-Fulani elite of the NPC. By contrast, the PDP carried all the Yoruba states by huge margins in 2003 (see below). In 1999 Obasanjo garnered only 20 per cent of the vote in the South West Yoruba states whereas in 2003 he received nearly 89 per cent. 
Comparison of 1999 and 2003

Presidential Election Results in the South West

\begin{tabular}{|l|ccc|ccc|}
\hline State & \multicolumn{3}{|c|}{ ANPP* } & & \multicolumn{3}{c|}{ PDP } & \\
& $\mathbf{1 9 9 9}$ & $\mathbf{2 0 0 3}$ & Loss & $\mathbf{1 9 9 9}$ & $\mathbf{2 0 0 3}$ & Gain \\
\hline \multirow{2}{*}{ Ekiti } & $\%$ & $\%$ & $\%$ & $\%$ & $\%$ & $\%$ \\
Lagos & 73.15 & 2.3 & -70.85 & 26.85 & 92.42 & +65.57 \\
Ogun & 88.07 & 7.15 & -80.92 & 11.93 & 69.35 & +57.42 \\
Ondo & 69.83 & .05 & -69.78 & 30.17 & 99.92 & +69.75 \\
Osun & 75.37 & 3.6 & -81.77 & 16.63 & 94.61 & +77.98 \\
Oyo & 76.47 & 2.35 & -74.12 & 23.53 & 95.0 & +71.47 \\
\hline
\end{tabular}

*The ANPP was known as the APP in 1999

Note: Official figures for Ondo's 1999 vote totals come to over $100 \%$

\section{CONCLUSION}

At present, Nigeria is caught between Huntington and his 'two turnover test' and those like Karl, who warn of an electoral fallacy. Holding the elections on time is a momentous accomplishment, especially given the scale of the task in a country with 120-million people. Keeping violence to a minimum in most places while ballots were cast is also a notable accomplishment. The role of election monitors and the support of the international community were probably crucial in this regard. Although the actual numbers of international monitors were small in relation to the number of polling stations, support for the massive civil society effort and the electoral administrative apparatus was substantial and available early. To be sure, the military presence also played a role, but with impunity for human rights problems an ongoing concern, the larger framework of politics suggests this cooperation was not entirely cost free.

Civil-military relations as a potential snag in the consolidation process have not gone away either. The government could pave the way to peaceful elections by pursuing prosecutions in cases of election violence, which could have an important effect on de-legitimising violence as a tactical option for supporters. Future elections would benefit from clearer designation of the responsibilities of the police, the military, and local private security organisations and the resolution of legal ambiguities in their respective spheres of authority.

The election results themselves offer a mixed assessment for consolidation of democracy based on the several definitions offered at the outset of this paper. On the 
one hand, the proliferation of parties could be interpreted as a movement towards greater political competition, along the lines anticipated by Dahl. Despite its singlemember district plurality electoral system, Nigeria has always been something of an anomaly, with five parties seeking the presidency in 1979, six in 1983, three in 1999, and twenty-two in 2003. This is even more unusual in view of the predominance of three major geographically concentrated ethnicities. In reality, though, the country may be inching towards a two-party system now that the AD holds only eight per cent of the House and five per cent of the Senate seats. Duverger may have been right after all, but in the short term this may mean the political disenfranchisement of minorities and those excluded from the ruling party's umbrella.

On the other hand, the expansion of the PDP's umbrella carries mixed blessings for democracy's cause. True, the party now cuts across ethnic cleavages, as Lijphart suggests is healthy for a new democracy. However, it appears to have done so by simply internalising political competition within parties rather than promoting competition among them. This is evident in the lack of transparency in the primaries as well as the irregularities in the elections (although many parties share the blame here). The PDP may have to choose between the appearance of a popular mandate at the polls and the reality of popular opposition.

Efforts to minimise internal opposition through party discipline have triggered impromptu dismissals of important figures such as the Speaker of the House and the former chairman of the party, rather than less severe punishment such as loss of perks, scheduling privileges or committee assignments in the National Assembly. The courts, which generally played a positive role in the recent election process, have ruled that political parties have the last word in their internal affairs, including the selection of candidates (Ojeifo; Kalu April 2003). This may serve to some extent to insulate the party apparatus from presidential whim, but the public interest will still not be served without greater transparency of those internal affairs, particularly if there is more competition outside of the public domain. Legitimacy and transparency are inextricably linked in democratic processes.

Section 419 of Nigeria's criminal law covers financial fraud, and the date of the presidential election (4-19 April) struck Nigerians as a humorous coincidence. In the end, it is encouraging that on 29 April 2003, Nigerians successfully installed a new civilian government. A process to entrench democracy has begun and support from the international community remains crucial if Nigeria is to continue to move forward. For the 2007 elections, this will require the resolution of outstanding electoral disputes, bold new measures to curb political violence, and the remobilisation of civil society. For now, the elections have bought a measure of stability, but this brief opportunity to reform the political process should not be squandered. 


\section{REFERENCES}

\section{Books, Journal Articles and Reports}

Bratton, Michael. 1999. 'Second Elections in Africa'. In Diamond, Larry and Marc Plattner (eds). Democratization in Africa. Baltimore and London: Johns Hopkins University Press.

Dahl, Robert. 1971. Polyarchy: Participation and Opposition. New Haven and London: Yale University Press.

Diamond, Larry. 1996. 'Is the Third Wave Over?' Journal of Democracy 7, pp 20-37. Falola, Toyin and Julius Omozuanvbo Ihonvbere. 1985. The rise $\mathcal{E}$ fall of Nigeria's Second Republic, 1979-84. London, Totowa, NJ, USA: Zed Books. US distributor, Biblio Distribution Center.

Human Rights Watch. 2003. Testing Democracy: Political Violence in Nigeria 15 (8)(A), April.

Huntington, Samuel P. 1991. The Third Wave: Democratization in the Late Twentieth Century. Norman OK: University of Oklahoma Press.

IDASA. 2003. IDASA Weekly Updates on Election Related Violence and Conflict, Abuja, Nigeria.

Karl, Terry Lynn. 1990. 'Dilemmas of Democratization in Latin America'. Comparative Politics 23, pp 1-21.

Lijphart, Arend. 1977. Democracy in Plural Societies: A Comparative Exploration. New Haven: Yale University Press.

2002. 'The Wave of Power-Sharing Democracy'. In Andrew Reynolds (ed). The Architecture of Democracy: Institutional Design, Conflict Management, and Democracy in the Late Twentieth Century. Oxford: Oxford University Press.

Linz, Juan J and Alfred Stepan. 1996. Problems of Democratic Transition and Consolidation. Baltimore: Johns Hopkins University Press.

Mainwaring, Scott. 1992. 'Transitions to Democracy and Democratic Consolidation: Theoretical and Comparative Issues'. In Mainwaring, Scott, Guillermo O'Donnell, and J. Samuel Valenzuela (eds). Issues in Democratic Consolidation: The New South American Democracies in Comparative Perspective. Notre Dame, Indiana: University of Notre Dame Press.

Oyediran, Oyeleye. 1981. 'Presidential Election Result Controversy'. In Oyeleye Odiran (ed). The Nigerian 1979 elections. Lagos Nigeria: Macmillan Nigeria.

Rustow, Dankwart A. 1970. 'Transitions to Democracy: Toward a Dynamic Model'. Comparative Politics, pp 337-63.

Samuels, David J. 2003. Ambition, Federalism, and Legislative Politics in Brazil. Cambridge: Cambridge University Press.

Schedler, Andreas, Larry Jay Diamond, and Marc F Plattner. 1999. The self-restraining state power and accountability in new democracies. Boulder, Colo: Lynne Rienner Publishers. 
Shugart, Matthew S. and John Carey. 1992. Presidents and Assemblies. Cambridge: Cambridge University Press.

Transition Monitoring Group. 2003. ‘Preliminary Report on the National Assembly Elections', April.

\section{Media}

Adebayo, Mohammed. 2003. 'Getting Out of the Quagmire'. ThisDay, 13 April.

Adeniyi, Olusegun. 2003. ' ... Lack of Presidential Candidate, Bane of AD'. ThisDay, 20 April.

Akinola, Wale. 2003. Interview with Chief Abraham Adesanya: 'How AD/PDP Pact Backfired'. Sunday Vanguard, 20 April.

Akunna, Chuks. 'Ogbeh: Na'Abba's Suspension from PDP Stays'. ThisDay, 10 April 2003.

Amaize, Emma. 2003. ‘Thugs Kidnap Edo ANPP Chairman'. Vanguard, 15 January. Amanze, Obi and Ademola Adeyemo. 2003. ‘Osimore Wins from Prison'. ThisDay 14 April.

Anaba, Innocent. 2002. 'Political Party Registration: INEC, Groups Differ on Supreme Court Verdict'. Vanguard, 11 November.

Aziken, Emmanuel. 2003. 'APGA: Ojukwu Picks Bayero as Running Mate'. Vanguard, 11 January.

Fadeyi, Rotimi and Tobi Soniyi. 2002. 'INEC Asks Court to Void Electoral Act'. The Punch, 1 November.

'Gunmen Kill Nigerian Politician'. 23 September 2002.

Ibrahim, Saka. 2003. 'Gombe: Thugs Unleash Terror on Minister, Guber Candidate'. ThisDay, 13 February.

Ilorin, Abiodun Fagbemi. 2003. 'Suspected Political Thugs Kill Kwara ANPP Chief'. The Guardian, 18 April.

Ior, Daniel. 2003. '7 Killed in PDP/ANPP Clash'. ThisDay, 22 February.

Kalu, Awa. 2003. 'Law and Human Rights: The Judiciary and the Electoral Process'. Vanguard, 18 April.

Obi, Amanze and Ademola Adeyemo. 2003 'Osimore wins from Prison'. ThisDay, 14 April.

Oderemi, Kunle. 2003. 'How the Mighty are Falling'. Sunday PUNCH, 20 April.

Ojeifo, Sufuyan. 2003. ‘Obasanjo, Ekwueme: The Gulf Widens'. Vanguard, 30 March. .PDP Expels Gemade'. Vanguard, 25 April.

Olaniyonu, Yusuph. 2003. 'Unease in North Over Alliance for Democracy's Lack of Candidate'. ThisDay, 13 February.

Omonobi, Kingsley, Habib Yacoob, and Rotim Ajayi. 2003. 'Saturday Polls: ANPP, 11 others Gang Up Against PDP'. Vanguard, 16 April.

Onyekamuo, Charles. 2003. 'Protests Trail PDP National Assembly Primaries in Anambra'. ThisDay, 10 January. 
The Comet. 2003. 'Resolution to Work and Vote Together by Kwara UNPP, NDP, ANPP and PDP', 17 April.

The Post Express. 2003. 'Police and Political Thugs'. Editorial, 16 April.

ThisDay. 2003. 'National Assembly: Decampment Reduces PDP Strength', 15 January. _. 2003. Communiqué, 17 April.

Ughegbe, Lemmy and Olasunkanmi Akoni. 2002. ‘Unregistered Parties vs INEC: Supreme Court Admits Error in Ruling'. Vanguard, 15 November.

—. 2003. 'Ekwueme Loses Round One as Court Dismisses Motion'. Vanguard, 25 January.

UNIRIN. 2003. 'Nigeria: Opposition Party Picks Former Military Ruler as Candidate', 14 January.

- 2003. ‘Nigeria: Obasanjo's Nomination Challenged', 21 January.

Vanguard. 2003. 'The ANPP Primaries', 13 March.

Yacoob, Kingsley, Habib, Omonobi, and Rotimi Ajayi. 2003. 'Saturday Polls: ANPP, 11 Others Gang Up Against PDP'. Vanguard, 16 April. 